\title{
CHEMISTRY AND ANTITUMOUR ACTIVITY OF 5-BROMOURACILE'S DERIVATIVES
}

Elena Welchinskaya, Bogomolets National Medical University in Kiev, elena_wwu@ukr.net

\begin{abstract}
Problem of the treatment of man's cancer and search of the effective, with a little toxicity antitumour medical products, is one from the important task at the contemporaneous medicine and pharmaceutical chemistry. Chemical modification of molecular of 5-bromouracile with next investigation of toxicity and antitumour activity of its new derivatives which synthesized is described. Physical-chemical, statistical pharmacological, toxicological methods were used. A strongly antitumour effect has been discovered for bis-derivative of 5-bromouracile for the first time. A new convenient methods for the preparation of new mono- and bis-derivatives of 5-bromouracile with 1,1,1-trifluoro-2-bromo-2-chloroethane (ftorotan) and 1,1-diethylcarboxy-2-chloro-2-trifluoromethylethylene is described. The reactions are catalyzed by the DB18-crown-6-complex. It was tested on the heterotransplantates of man's glioma cancer of brain (by Bogden's under capsule-method). It is permits to consider the new bis-derivative of 5-bromouracile as physiological active with a perspective investigation as potential antitumour drugs for treatment of man in future.
\end{abstract}

UDC Number: 547.431 .4 - 547.854.4, 547.96, DOI: $10.12955 /$ cbup.2013.45

Keywords: 5-bromouracile, ftorotan, tumour, toxicity

\section{Introduction}

Problem of the treatment of man's cancer and search of the effective, non-toxically antitumour medical products is one of important task at the modern medicine. Knowledge of cancer's cell's specifics and metabolism permits to plan the main direction of the chemical and biological investigations, to carry out purposeful synthesis of the potential drugs, to mark the possibility of its using at the practice of oncology as antitumour medical products. Medical drugs - heterocyclic derivatives (treatment of cancer of alimentary canal and other) at the arsenal of antitumour drugs took the important place as Abou - Gharbia et al. (1988), Alonso et al. (1984) and Perevodchikova et al. (2005) write. Heterocyclic systems such as: 5(6)-substituted uraciles, pyrimidines; are main components of antitumour drugs, anxiolytic agents or bactericides as Adjei (1999), Barlow (1959), Anderson et al. (1992), Anttila et al. (1983), Benz et al. (1982), Longley et al. (2004) and Noordhuis et al. (2004) write. Molecules of 5(6)-fluoric-(halogen)-substituted uraciles and its derivatives can to play a role of halogen containing syntones at organic synthesis, therefore these compounds are actively using for the building of original biological activity molecules. Besides that, halogen substituted groups and fragments to increase of it are soluble at the lipids. It is help to prepare medical drugs, which more effective (easiness in transportation inside the organism) as Au et al. (1979), Baba et al. (2000) and Yagupolskiy (1988) write. In this paper we report the synthesis, characterization, toxicity and antitumour activity of new mono- and bis-adducts of 5-bromouracile and ftorotan or fluoric 
containing ethylene. It is necessary to accented that compounds of our investigation has heterocyclic fragment which are connected with remainder of molecule ftorotan - widely using at the surgical oncological practice (Brody, 1963; Brown, 1977). The derivatives of 5-bromouracile and ftorotan I-III are obtained under phase-transfer conditions in alkaline medium. The reactions are catalysed by DB18-crown-6-complex. The method reported for the synthesis of adducts I-III is based on the reactions which involve elimination of fluorine hydride, formation of the intermediate 1,1-difluoro-2-bromo-2chloroethene, which reacts with nucleophilic molecules as Yagupolskiy (1988) writes. New polyfunctional compound IV for using at the reactions with nucleophilic uracile was obtained. Original substituted 5-bromouracile with fluoric containing ethylene group IV is obtained at system of dry solvents DMFA-ethyl ester in presence of triethylamine anhydrous for the first time. The general synthetic procedures used for their preparation are illustrated in Schemes I-III.

Scheme I: Synthesis of new compounds with groups $-\mathrm{CF}_{2}-\mathrm{CHBrCl},-(\mathrm{HO}) \mathrm{C}=\mathrm{CBrCl}(\mathrm{I}, \mathrm{II})$
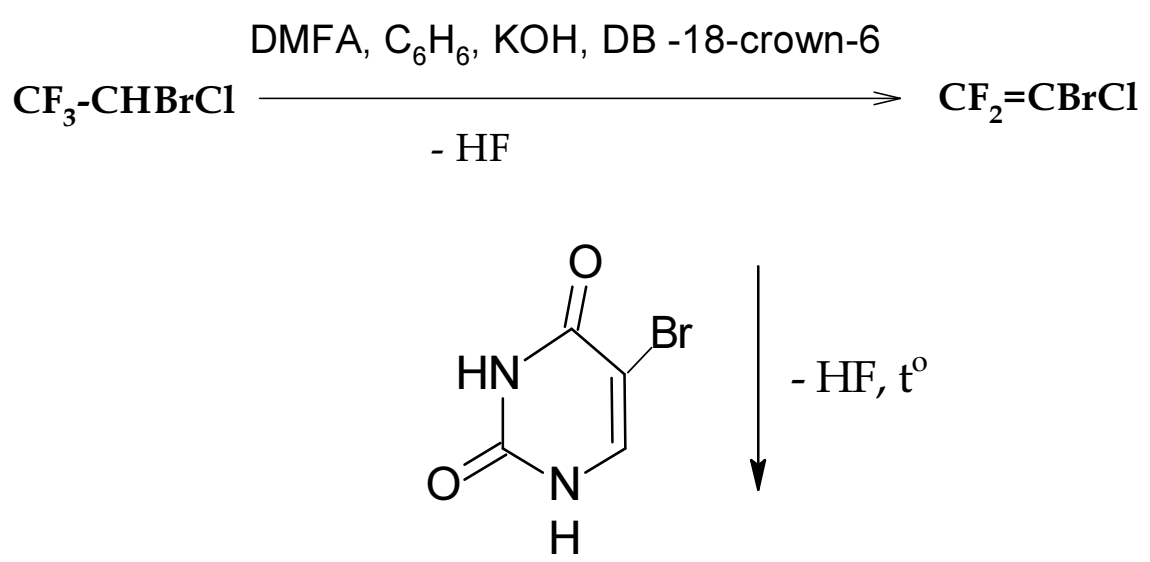

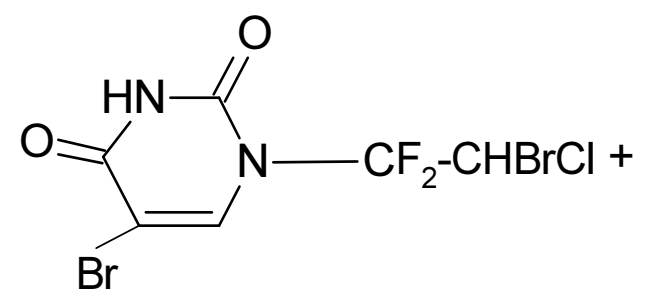

I<smiles>CC(=C(Cl)Br)n1cc(Br)c(=O)[nH]c1=O</smiles>

II

Source: Author

New compounds I-IV were tested on the heterotransplantates of man's glioma cancer of brain (by Bogden's under capsule-method).

\section{Methods}

The majority of the absolute organic solvents (benzene, dimethylformamide (DMFA), hexane, ethyl ester) employed in the present studies were distilled before use. Organic solvents were dried over anhydrous magnesium sulfate or metallic sodium. Gas-liquid chromatography carries out on Perkin 
Elmer chromatograph with UV-detector ("Perkin", Germany). IR spectra were recorded in a UR-20 spectrometer ("Charles Ceise Hena", Germany).

Scheme II: Synthesis of new compound with group $=\mathrm{C}=\mathrm{CBrCl}$ (III)

Scheme III: Synthesis of new compounds with groups $-\left(\mathrm{CF}_{3}\right) \mathrm{C}=\mathrm{C}\left(\mathrm{COOC}_{2} \mathrm{H}_{5}\right)_{2}(\mathrm{IV}, \mathrm{V})$

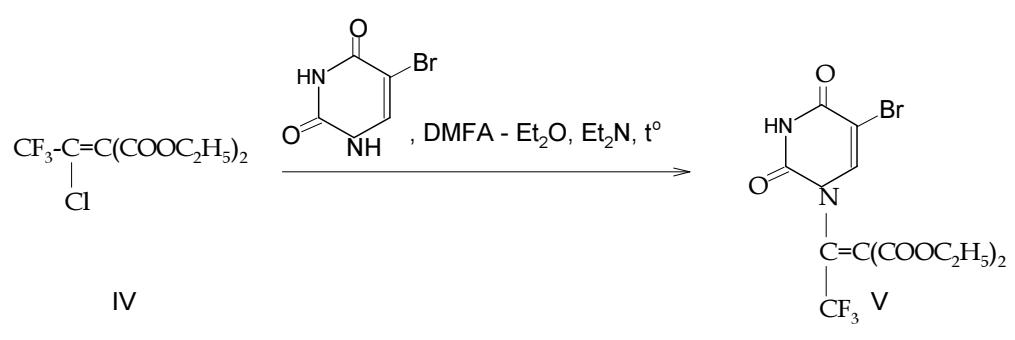

Source: Author

The ${ }^{1} \mathrm{H}$ NMR spectra were recorded in DMSO- $\mathrm{d}_{6}$ on a $200 \mathrm{MHz}$ BrakerWP-200 ("Braker", Switzerland) or Varian T-60 spectrometer ("Varian", USA). New compounds with significant antitumour action selected and investigated (Welchinska, 2003). The white imbredical mice and experimental model of tumour growth (operation and biopsy materials of man's glioma cancer of brain, heterotransplantates) were used following published procedures as Perevodchikova et al. (2005) writes. The experimental tumours used for our investigation were obtained from Bank of stammes of Oncological Centre of Russian Academy of Medical Sciences. The experimental tumours were used for passage on experimental animals, program freezing and, after that, these were preserved in Bank of stammes of Institute of Pharmacology and Toxicology of National Academy of Medical Sciences of Ukraine. The efficiency parameter [\% of growth relaxation of tumour, (volume and mass)] is $\geq 25 \%$. The results were assessed by standard methods of statistical analysis (Prozorovskiy, 1978; Sophina, 
1979). Investigation of critical toxicity of new compounds was carrying out at Institute of Pharmacology and Toxicology of National Academy of Medical Sciences of Ukraine. Way of introduction - under skin.

\section{Chemistry and antitumour activity of 5-bromouracile's derivatives}

Chemistry. General procedure of the preparation of $\mathrm{N}_{(1)}-\left(1^{\prime}, 1\right.$ '-difluoro-2'-bromo-2'-chloroethyl)-5bromouracile (I), $\mathrm{N}_{(1)}-(2$ '-bromo-1'-hydroxy-2'-chloroethenyl)-5-bromouracile (II).

Solution I. A mixture of potassium hydroxide $(0.44 \mathrm{~g}, 0.0079 \mathrm{~mol})$ and dibenzo- 18 -crown-6-complex $(0.044 \mathrm{~g}, 0.0079 \mathrm{~mol})$ in $20 \mathrm{ml}$ of dry benzene was heated under reflux at $60-80^{\circ} \mathrm{C}$ for $15 \mathrm{~min}$. The cooled solution was mixed with ftorotan $(1.57 \mathrm{~g}, 0.84 \mathrm{ml}, 0.0079 \mathrm{~mol})$ in $20 \mathrm{ml}$ of dry ethyl ester. A solution I was heated under reflux at $60-80^{\circ} \mathrm{C}$ for $15 \mathrm{~min}$. After that the cooled solution I was mixed with solution II [5-bromouracile $(1.51 \mathrm{~g}, 0.0079 \mathrm{~mol})$ in $40 \mathrm{ml}$ of dry dimethylformamide] and then heated under reflux at $60-80^{\circ} \mathrm{C}$ for $7 \mathrm{~h}$. The heated solution was filtered. The precipitate was washed with $30 \mathrm{ml}$ of mixture of ethyl ester-hexane (1:1), dried under vacuum. The adduct $\mathrm{I}$ is a creamcolored solid (42\%). Melting point: $282-285^{\circ} \mathrm{C}$. Found, \%: C 19.44; $\mathrm{H}$ 0.80; N 7.53. $\mathrm{C}_{6} \mathrm{H}_{3} \mathrm{Br}_{2} \mathrm{ClF}_{2} \mathrm{~N}_{2} \mathrm{O}_{2}$. Calculated, \%: C 19.56; $\mathrm{H} \mathrm{0.82;} \mathrm{N} \mathrm{7.60.} \gamma_{\max }(\mathrm{KBr}), \mathrm{cm}^{-1} 550-690,1710,1750 ; \sigma \mathrm{H}$ 5.678-5.689 (1H, J $\left.{ }^{3} \mathrm{H}, \mathrm{F} 5.4 \mathrm{~Hz}, \mathrm{~J}_{\mathrm{H}, \mathrm{Cl}(\mathrm{Br})}^{2} 0.8 \mathrm{~Hz}, \mathrm{CF}_{2} \mathrm{CHBrCI}\right), 7.228\left(1 \mathrm{H}, \mathrm{C}_{(6)} \mathrm{H}\right), 10.562\left(1 \mathrm{H}, \mathrm{N}_{(3)} \mathrm{H}\right)$. Cooled filtrate stay per night. Remainder (adduct II) - oil which crystallized from the mix of ethyl ester-hexane (1:1). Solid, which obtained dried on the air (10.5\%). Melting point: $274-277^{\circ} \mathrm{C}$. Found, \%: C 20.33; $\mathrm{H}$ 0.89; $\mathrm{N}$ 7.88. $\mathrm{C}_{6} \mathrm{H}_{3} \mathrm{Br}_{2} \mathrm{ClN}_{2} \mathrm{O}_{3}$. Calculated, \%: C 20.80; H 0.87; N 8.08. $\gamma_{\max }(\mathrm{KBr}), \mathrm{cm}^{-1}$ 550-690, 1710, 1750, 3200-3400; $\sigma \mathrm{H} 7.228\left(1 \mathrm{H}, \mathrm{C}_{(6)} \mathrm{H}\right), 10.562\left(1 \mathrm{H}, \mathrm{N}_{(3)} \mathrm{H}\right), 10.974(1 \mathrm{H}, \mathrm{OH})$. $N_{(I)}, N_{\left(l^{\prime}\right)}-\left(2^{\prime \prime}\right.$-bromo-2"-chloroethenyl)-bis-(5-bromouracile) (III). The adduct was prepared according to the general procedure. The adduct III is a cream-colored solid $(30 \%)$. Melting point: $270-275^{\circ} \mathrm{C}$. Found, \%: C 22.8; $\mathrm{H} 1.02 ; \mathrm{N} \mathrm{10.75;} \mathrm{Br}$ 45.96. $\mathrm{C}_{10} \mathrm{H}_{4} \mathrm{Br}_{3} \mathrm{ClN}_{4} \mathrm{O}_{4}$. Calculated, \%: C 23.13; $\mathrm{H} \mathrm{0.77;} \mathrm{N}$ 10.78; $\mathrm{Br} 46.1 . \gamma_{\max }(\mathrm{KBr}), \mathrm{cm}^{-1} 550-695,1710,1750 ; \sigma \mathrm{H} 4.048\left(2 \mathrm{H}, 2 \mathrm{~N}_{(3)} \mathrm{H}\right.$ in $\left.\mathrm{H}_{2} \mathrm{O}\right), 7.66(2 \mathrm{H}$, $\left.2 \mathrm{C}_{(6)} \mathrm{H}\right)$. 1,1-diethylcarboxy-2-treefluoromethyl-2-chloroethylene (IV). A mixture of metallic sodium $(6.13 \mathrm{~g}, 0.268 \mathrm{~mol})$ in $250 \mathrm{ml}$ of methanol anhydrous, diethyl ester of malonic acid $(43.0 \mathrm{~g}, 40 \mathrm{ml}$, $0.268 \mathrm{~mol})$ and treefluoroacetic acid $(62.0 \mathrm{~g}, 40 \mathrm{ml}, 0.543 \mathrm{~mol})$ was heated under reflux at $60-80^{\circ} \mathrm{C}$ for $6 \mathrm{~h}$. To the product - glass-shape mass with white color added ethyl ester. The precipitate is whitecolored solid (product A). A mixture of product A $(8.0 \mathrm{~g}, 0.0287 \mathrm{~mol})$ in $55 \mathrm{ml}$ of dry dichloroethane and phosphorus pent chloride $(6 \mathrm{~g}, 0.0287 \mathrm{~mol})$ was heated with boiling for $5 \mathrm{~h}$. The precipitate was filtered and washed with dichloroethane. The adduct IV is oil $(80 \%)$. Boiling point: $56-59^{\circ} \mathrm{C}(25 \mathrm{~mm}$ of merc. column), $\mathrm{n}^{25}$ 1.3010. Found, \%: C 39.36; $\mathrm{H}$ 3.67; F 20.75. $\mathrm{C}_{9} \mathrm{H}_{10} \mathrm{ClF}_{3} \mathrm{O}_{4}$. Calculated, \%: C 39.37; H 3.64; F 20.76. $\gamma_{\max }(\mathrm{KBr}), \mathrm{cm}^{-1} 400,415,470,560,730,905,995,1180,1230,1295,1315$, 1600, 1735, 2800-3000; $\sigma \mathrm{H} 1.19\left(6 \mathrm{H}, \mathrm{J}_{\mathrm{H}, \mathrm{H}}^{3} 7.2 \mathrm{~Hz}, 2 \mathrm{CH}_{3}\right), 4.10\left(4 \mathrm{H}_{1} \mathrm{~J}_{\mathrm{H}, \mathrm{H}}^{3} 7.2 \mathrm{~Hz}, 2 \mathrm{OCH}_{2}\right) .1,1-$

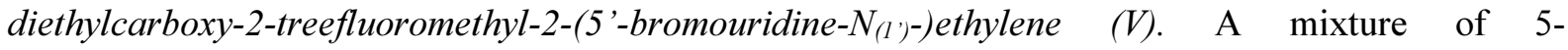
bromouracile $(0.34 \mathrm{~g}, 0.001 \mathrm{~mol})$ in $30 \mathrm{ml}$ of dry dimethylformamide, anhydrous tree-ethylamine $(0.18 \mathrm{~g}, 0.24 \mathrm{ml}, 0.001 \mathrm{~mol})$ and the adduct IV $(0.5 \mathrm{~g}, 0.001 \mathrm{~mol})$ in $15 \mathrm{ml}$ of dry diethyl ester was

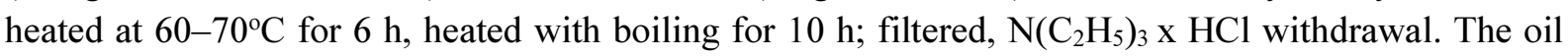
yellow-colored was washed with $10 \mathrm{ml}$ of hexane, $10 \mathrm{ml}$ of acetone. The adduct $\mathrm{V}$ is a rose-colored solid (33\%). Melting point: $255-260^{\circ} \mathrm{C}$. Found, \%: C 37.03; H 2.40; N 6.48; $\mathrm{Br} 19.0 . \mathrm{C}_{13} \mathrm{H}_{12} \mathrm{BrF}_{3} \mathrm{~N}_{2} \mathrm{O}_{6}$. Calculated, \%: C 36.4; H 2.8; N 6.50; Br 18.64. $\gamma_{\max }(\mathrm{KBr}), \mathrm{cm}^{-1} 400,415,470,560,600-800,905$, $995,1180,1230,1295,1050-1150,1300-1600,1315,1600,1710,1715,3010-3080$; $\sigma \mathrm{H} 2.54(6 \mathrm{H}$, $\left.\mathrm{J}_{\mathrm{H}, \mathrm{H}}^{3} 7.2 \mathrm{~Hz}, 2 \mathrm{CH}_{3}\right), 4.0-4.36\left(4 \mathrm{H}, \mathrm{J}_{\mathrm{H}, \mathrm{H}}^{3} 7.2 \mathrm{~Hz}, \mathrm{~J}^{2}{ }_{\mathrm{H}, \mathrm{H}} 3.6 \mathrm{~Hz}, 2 \mathrm{OCH}_{2}\right), 7.76\left(1 \mathrm{H}, \mathrm{C}_{(6)} \mathrm{H}(\mathrm{Het})\right), 11.04(1 \mathrm{H}$, $\left.\mathrm{N}_{(3)} \mathrm{H}(\mathrm{Het})\right)$. 
Biology. All isolated males of imbredical mice were provided with standard food ration in all groups with the same control. The quantity of animals in each group was six. Minimum mass of mice body was $17.0 \pm 2.0 \mathrm{~g}$. The age of the mice was $2-3$ months. Percentage primary recovery and destruction is ' 0 '. Method of killing was decapitation, redosage of ethyl ester. The method of removal of the experimental tumours is surgical. The efficiency parameter [\% of growth relaxation of the tumour (volume and mass)] was counted by the formula (Sophina, 1979):

(middle data of tumour growth in control) - (middle data of tumour growth in experimental group) / (middle data of tumour growth in control) $\times 100 \%$.

There were six introductions of the physiological solutions of adducts I-III, V every day. The dosage of the preparations corresponded to $1 / 4-1 / 6$ of the $\mathrm{LD}_{50}$. Results after $24 \mathrm{~h}$ of finishing of treatment were calculated. The main control data are: middle mass of the tumour of the control animals $(\mathrm{g})$; middle mass of the tumour of the experimental animals (g); \% of growth relaxation of the tumour; index of effectivity; spleen coefficient. The criteria of considerable is $>25.0 \%$ of growth relaxation of the tumour. Preparation of standard was 5-flurouracile (5-FU). The express-method of definition of $\mathrm{LD}_{50}$ was used (Prozorovskiy, 1978). Results were calculated at alternative form after 2 weeks after the introductions. Statistical analysis carries out by (Perevodchikova, 2005). The doses of substances were from 600 to $250 \mathrm{mg} / \mathrm{kg}$. Tonic convulsions during $1-2 \mathrm{~h}$, vomiting at experimental animals were observed.

\section{Results and Discussions}

The chemical composition and structure of new mono- and bis-adducts of 5-bromouracile have been studied. It has been shown that mono- and bis-adducts of 5-bromouracile I, II, III are less toxicity (in $1.05-1.11$ ones), than $5-\mathrm{FU}\left(\mathrm{LD}_{50}\right.$ is $375 \mathrm{mg} / \mathrm{kg}$ ). Meanings of its $\mathrm{LD}_{50}$ are from $415 \mathrm{mg} / \mathrm{kg}$ up to 396 $\mathrm{mg} / \mathrm{kg}$. Data of toxicity of these products are shown in Table 1.

Table 1: Parameters of toxicity of compounds I-III, compared with 5-fluorouracile

\begin{tabular}{|l|l|c|}
\hline No. & \multicolumn{1}{|c|}{ Adduct } & $\mathrm{LD}_{50}, \mathrm{mg} / \mathrm{kg}$ \\
\hline 1. & $\mathrm{~N}_{(1)}-\left(1^{\prime}, 1^{\prime}\right.$ '-difluoro-2'-bromo-2'-chloroethyl)-5-bromouracile (I) & 396.00 \\
\hline 2. & $\mathrm{~N}_{(1)}-\left(2^{\prime}\right.$-bromo-1'-hydroxy-2'-chloroethenyl)-5-bromouracile (II) & 399.00 \\
\hline 3. & $\mathrm{~N}_{(1)}, \mathrm{N}_{\left(1^{\prime}\right)}-\left(2^{\prime \prime}-\right.$-bromo-2"-chloroethenyl)-bis-(5-bromouracile) (III) & 415.00 \\
\hline 4. & $5-\mathrm{FU}$ (control)* & 375.00 \\
\hline
\end{tabular}

Source: Author; * Prozorovskiy, V. B. et al. (1978); Sophina, Z. P. et al. (1979)

It has been established that bis-adduct of 5-bromouracile III has the antitumour activity. After treatment by bis-adduct III the mass of heterotransplantates of man's glioma cancer reduced from $2.68 \pm 0.102 \mathrm{mg}$ to $1.51 \pm 0.102 \mathrm{mg}$. It's $43.8 \%$ of growth braking of the cancer's growth (criteria of considerable is $>25.0 \%$ of growth relaxation of the tumour). It's in 1.75 ones more than standard criteria during the treatment of glioblastome which confirmed by carry out of morphological control.

\section{Conclusion}

New mono- and bis-adducts of 5-bromouracile were prepared and tested for their toxicity and antitumour activity on the heterotransplantates of man's glioma cancer of brain (operation and biopsy 
materials; by Bogden's under capsule-method). A new convenient methods for the preparation of heterocyclic mono- and bis-adducts I-III, $\mathrm{V}$ of 5-bromouracile with 1,1,1-trifluoro-2-bromo-2chloroethane (ftorotan) or 1,1-diethylcarboxy-2-chloro-2-trifluoromethy-lethylene are described. The reactions are catalyzed DB-18-crown-6-complex (at the alkali medium). Investigation of the critical toxicity of compounds which synthesized shows it has a little toxicity: $\mathrm{LD}_{50}$ from $415 \mathrm{mg} / \mathrm{kg}$ up to 396 $\mathrm{mg} / \mathrm{kg}$. Antitumour activity of bis-adduct of 5-bromouracile III permits to consider it as physiological active with a perspective investigation as potential antitumour drugs for treatment of man in future.

\section{References}

Adjei, A. A. (1999). Review of pharmacology and clinical activity of new chemotherapy agents for the treatment of colorectal cancer. Clinical Pharmacology, Vol. 48, p. 265-277.

Abou - Gharbia, M. \& Patel - Usha, R. (Eds.). (1988). Polycyclic aryl- and heteroarylpiperazinyl imides as $5-\mathrm{HT}_{1 \mathrm{~A}}$ receptor ligands and potential anxiolytic agents: synthesis and structure-activity relationship studies. Journal of Medical Chemistry, Vol. 31 (7), p. 1382-1385.

Alonso, R., Shaw G. \& Wright D. (1984). Thermal addition of heterocycles to bicyclic reagents. Journal Chemical Society Perkin Translation, 1 (12), p. 2795-2799.

Anderson, N. \& Lokich, J. (1992). Controversial issues in 5-fluorouracil infusion use. Dose intensity, treatment duration, and cost comparisons. Cancer, 70, p. 998-1002.

Anttila, M. I., Sotaniemi, E. A. \& Kairaluoma, M. I. (Eds.). (1983). Pharmacokinetics of ftorafur after intravenous and oral administration. Cancer Chemotherapy and Pharmacology, 10, p. 150-153.

http://dx.doi.org/10.1007/BF00255750

Au, J. L., Wu, A. T. \& Friedman, M. A. (Eds.) (1979). Pharmacokinetics and metabolism of ftorafur in man. Cancer Treatment Rep., 63, p. 343-350.

Baba, H., Kohnoe, S. \& Endo, K. (Eds.) (2000). State of the treatment for gastrointestinal cancer. Gan To Kagaku Ryoho., Vol. 27, p. 1233-1246.

Barlow, R. (1959). Vvedenie v himicheskyy farmacologiy [Introduction to chemical pharmacology]. Moscow, Russia: Foreign literature.

Benz, C., Tills, T. \& Tattelman, E. (Eds.) (1982). Optimal schedule of methotrexate and 5-fluorouracil in human breast cancer. Cancer Research, Vol. 42, p. 2081-2086.

Brody, G. L. \& Sweet, R. B. (1963). Halothane anesthesia as a possible cause of massive hepatic necrosis. Anesthesiology, Vol. 24, p. 29-37. http://dx.doi.org/10.1097/00000542-196301000-00005

Brown, B. R. \& Sipes, I. G. (1977). Biotransformation and hepatotoxicity of halothane. Biochemical Pharmacology, Vol. 26, p. 2091-2094. http://dx.doi.org/10.1016/0006-2952(77)90256-8

Longley, D. B. \& Harkin, D. P. (2004). Mechanisms of action of 5-fluorouracil. Nature Revues Cancer, Vol. 4, p. 230-238.

Noordhuis, P. \& Holwerda, U. (2004). 5-fluorouracil incorporation info RNA and DNA in relation to thymidilate synthetase inhibition human colorectal cancer. Annals of oncology, Vol. 15, p. 1025-1032. http://dx.doi.org/10.1093/annonc/mdh264 PMid:15205195 
Perevodchikovoy, N. I. (Ed.) (2005). Chimioterapia rakovih zabolevaniy [Chemotherapy of cancerous diseases] ( $2^{\text {nd }}$ edition). Moscow, Russia: Practical medicine.

Prozorovskiy, V. B., Prozorovskiy, V. P. \& Demchenko, V. M. (1978). Ekspress-metod opredeleniya sredney effektivnosty dozy i ego oshibka [Express - method of middle effective dose determination and its mistake]. Pharmacology and toxicology, Vol. 41 (4), p. 407-509.

Sophinoy, Z. P., Sophina, A. B., Goldina, A. \& Kmeina, A. (Eds.) (1979). Eksperimentalnay ocenka protivoopuholevyh preparatov v SSSR i SShA [The experimental value of the antitumour drugs in USSR and USA]. Moscow, Russia: Medicine.

Welchinska, H. V., Piecuszak, B. I. \& Kovalenko, E. A. (Eds.) (2003). Biologicheskaya aktivnost bakterialnih lektinov i ih molekularnih kompleksov s geterotsyklicheskimy bis-adduktamy [Biological activity of bacterial lectins and their molecular complexes with heterocyclic bis-adducts].

Microbiological journal, Vol. 65 (6), p. 20-25.

Yagupolskiy, L. M. (1988). Aromaticheskie i geterocyklicheskie soedineniya s ftorsoderjashimy zamestitelyamy [Aromatic and heterocyclic compounds with fluorocontaining substitutes]. (p. 90105). Kiev, Ukaine: Naukova dumka. 